\title{
MOLECULAR CHARACTERIZATION OF SOME EGYPTIAN SORGHUM BICOLOR GENOTYPES USING ISSR MARKERS
}

Nourhan A. Hanafy ${ }^{*}$, Rashed ${ }^{2}$ M.A., Shireen K. Assem ${ }^{1}$ and Madkour ${ }^{3}$ M.A.

1- Plant Molecular Biology, Agric. Genetic Eng. Research Institute, Agric. Research Center, Giza, Egypt

2- Genetics Dept., Fac. of Agric., Ain Shams Univ., P.O. Box 68, Hadayek Shoubra 11241, Cairo, Egypt

3- Biotechnology Dept., Arid Land Agric. Graduate Studies and Research Institute, Fac. of Agric., Ain Shams Univ., P.O. Box 68, Hadayek Shoubra 11241, Cairo, Egypt

${ }^{*}$ Corresponding author: nourhan.aiman@hotmail.com

Received 28 July, 2019

Accepted 12 January, 2020

\section{ABSTRACT}

Twenty Egyptian sorghum (Sorghum bicolor (L.) Monech) genotypes were assessed using 10 ISSR primers. The used ISSR primers yielded 152 amplified products (an average of 15.2 bands /primer). Eight out of these primers generated 24 unique markers among the 20 studied sorghum genotypes. However, molecular characterization revealed a polymorphism percentage of a $100 \%$ for ISSR markers. The used primers revealed a high level of polymorphism among the studied sorghum genotypes. On the other hand, cluster analysis using UPGMA analysis classified the 20 sorghum genotypes into two groups using the generated ISSR markers. The cluster analysis showed a high genetic variation among the studied sorghum genotypes and the diversity of these genotypes was compatable with their source pedigrees. The results of principle coordinate analysis (PCoA) were closely in line with those of the cluster analysis. These results could be used by breeders to improve the breeding programs for sorghum's performance and productivity.

Keywords: DNA; ISSR; Polymorphism; Sorghum; PCoA; UPGMA.

\section{INTRODUCTION}

Sorghum is considered as one of the commercial sources of syrup and/or sugar production besides sugarcane and sugar beet because it can tolerate climate factors of semi-arid regions ( $\mathrm{Da}$ Silva Neto et al 2019). It's also the fifth important cereal crop all over the world after rice, wheat maize and barley. Sorghum is the second African most important cereal and it's well adapted to tropical and sub-tropical areas. It enters in the industry of flour, fuel, source of fiber, the manufacture of fermentation and beer, extracting some chemical compounds like dextrin, windbreakers, building fences and fresh fodder crops especially in summer (Assem et al 2014).

The productivity of this crop could be improved, as it possesses a wide range of genetic diversity. The uses of modern techniques such as molecular markers are required to enhance its breeding programs. Important traits which are related to habitat adaptation and exhibit enormous variability among sorghum germplasm are complex and quantitatively inherited. Hence, classifying germplasm accessions based solely on a few discrete morphological characters may not provide an accurate indication of the genetic divergence among the cultivated genotypes of sorghum (Rashed et al 2004).

Several molecular markers are available, and the knowledge on the properties and applications of the species is necessary to choose the appropriate marker according to the profile of the study of interest (Souza et al., 2015). Molecular markers, which are identifiable DNA sequences specific to the genome, are useful tools in the exploration of genetic diversity and provide information on genetic variability by eliminating possible environmental effects (Soares et al 2016). RFLPs, RAPDs, and ISSRs are DNA marker profiling technologies that each shares the advantage of being readily available without the need for significant expenditures of resources for basic technology development (Smith et al 2000). 
ISSRs have high reproducibility use of longer primers (16-25 mers) when compared to RAPD primers (10 mers). The longer primers permits the subsequent use of high annealing temperature $\left(45-60^{\circ} \mathrm{c}\right)$ leading to higher stringency. Therefore, ISSR marker technique overcomes most of these limitations and it is rapidly being used by the breeders and researcher's community in Sorghum improvement. (El-Amin et al 2016). ISSRs are known to be present more in numbers, stable across the developmental stages, least influenced by environmental factors, devoid of the pleaotripic and epistatic effects. Its also dominant marker systems, simple, quick, less costly, easier to be developed and used as well as they have high reproducibility than RAPD primers due to the longer primer (Vijayan, 2005). ISSR is a PCR based technique, which reported by Ztetkiewicz et al (1994), and involves amplification of DNA segments between two identical microsatellite repeat regions oriented in opposite direction using primers designed from microsatellite core regions. ISSR primers generate polymorphism whenever one genome misses the sequence repeat or has a deletion or insertion or translocation that modifies the distance between the repeats. Usually di-nucleotide repeats anchored either at $3^{\prime}$ or $5^{\prime}$ end reveal high polymorphism (Nagaoka and Ogihara, 1997; Blair et al 1999; Joshi et al 2000).

After many studies, It was found that ISSR marker is more suitable for plant genetic diversity study with high polymorphism and more reproducibility than RAPD marker (Tadesse and Tileye. 2013).

From the commercial point of view, molecular fingerprinting is a useful tool for several applications, including its use in breeding programs, in determining relatedness of genotypes and for pedigree verification. Molecular fingerprints are useful for varietal protection to prove ownership or derivation of plant lines as well as to prove violations and breaching of patent and plant variety protection certificates or the misappropriation of trade secrets. Such techniques will play an increasingly important role in developing, acquiring and enforcing variety proprietary rights (Atta and El-Shimi, 2003).

The objectives of this study are to determine the molecular identification and fingerprinting of 20 Egyptian sorghum genotypes using 10 ISSR primers and to detect the genetic distance and relationships among these genotypes.

\section{MATERIAL AND METHODS}

\section{Plant material}

The 20 Egyptian sorghum genotype seeds (Table 1) were kindly provided by sorghum department at the Field Crops Research Institute, Agricultural Research Center which have been germinated in pots contained sand, clay and peat moss $(1: 2: 1)$ in the greenhouse of the Agricultural Genetic Engineering Research Institute, Agricultural Research Center and irrigated twice a week with a tap water, as well as temperature was $28^{\circ} \mathrm{C}$ with 16 hours lighting for 10 days. Then, fresh leaf samples were taken after 10 days to isolate DNA by Cetyl trimethylammonium bromide (CTAB) method (Doyle et al 1990).

Table 1. Names and codes of the 20 used (A \& B) Egyptian sorghum genotypes

\begin{tabular}{|c|c|c|c|}
\hline No. & Code & Cultivars A & Cultivars B \\
\hline $\mathbf{1}$ & 101 & ICSA 1 & ICSB 1 \\
$\mathbf{2}$ & 108 & ICSA 88005 & ICSB 88005 \\
$\mathbf{3}$ & 3 & ICSA 20 & ICSB 20 \\
$\mathbf{4}$ & 4 & ICSA 30 & ICSB 30 \\
$\mathbf{5}$ & 10 & ICSA 93 & ICSB 93 \\
$\mathbf{6}$ & 12 & ICSA 102 & ICSB 102 \\
$\mathbf{7}$ & 16 & ICSA 1836 & ICSB 1836 \\
$\mathbf{8}$ & 33 & ATX-626 & BTX-626 \\
$\mathbf{9}$ & 45 & AKS-10288 & BKS-10288 \\
$\mathbf{1 0}$ & 52 & SPDL(A)- & SPDL(B)- \\
& & 94031 & 94031 \\
\hline
\end{tabular}

\section{Methods}

\section{a) DNA extraction}

Two hundred mg of fresh leaves were harvested by liquid nitrogen. The harvested samples were transferred to a $1.5 \mathrm{ml}$ eppendorf tube contained a $1 \mathrm{ml}$ of CTAB (15 gm of CTAB, $41 \mathrm{gm}$ of $\mathrm{NaCl}, 20$ $\mathrm{ml}$ EDTA $20 \mathrm{mM}, 50 \mathrm{ml}$ Tris-HCL $100 \mathrm{mM}$ and up to $500 \mathrm{ml}$ of $\mathrm{dH}_{2} \mathrm{O}$ ), a $10 \mu \mathrm{l}$ of $\beta$ mercaptoethanol and a $0.2 \mathrm{gm}$ of PVP. Tubes were incubated in a thermoshaker at $65^{\circ} \mathrm{c}$ for 30 mins. A $700 \mu \mathrm{l}$ of chloroform and a $29 \mu$ l of isoamyl were added then tubes 

using ISSR markers

were centrifuged for 15 mins at $10,000 \mathrm{rpm}$. The aques phase was transferred to a new tube and an equal volume of isopropyl was added, then tubes were incubated at $-20^{\circ} \mathrm{c}$ for 30 mins. Tubes were centrifuged for 15 mins at $10,000 \mathrm{rpm}$, then a 500 $\mu \mathrm{l}$ of cold ethanol was added and centrifuged for 5 mins at $10,000 \mathrm{rpm}$. Other $500 \mu \mathrm{l}$ of cold ethanol was added and centrifuged for 5 mins at 10,000 rpm. Tubes were air dried and DNA was eluted in a $45 \mu \mathrm{l}$ of autoclaved $\mathrm{dH}_{2} \mathrm{O}$. The DNA was loaded in a $0.8 \%$ agarose gel, and its concentration was measured by the spectrophotometer which were between 1.1 to 4.8 for group $A$ and 0.6 to 15.8 for group $B$, as well as purity for group $A$ was between 1.3 to 2.0 and for group B was between 1.2 to 2.2 .

\section{b) ISSR-PCR amplification}

Ten ISSR primers sequences (Table 2) were obtained from Simth et al (2003), Tadesse \& Tileye (2013) and Mindaye et al (2015) of all sorghum chromosomes as they previously reported a high polymorphism. The polymerase chain reaction (PCR) was performed by using Go Taq ${ }^{\circledR}$ G2 Flexi
DNA polymeras (Promega) in a $25 \mu$ l of mixture containing a $5 \mu$ l of $5 x$ green go taq reaction buffer, a $1.5 \mu \mathrm{l}$ of $\mathrm{MgCl}_{2} 25 \mathrm{mM}$, a $0.5 \mu \mathrm{l}$ of dNTP's $10 \mathrm{mM}$, a $1 \mu \mathrm{l}$ of ISSR primer $20 \mathrm{pmol}$, a $1 \mu \mathrm{l}$ of diluted preheated DNA (a $1 \mu \mathrm{l}$ of DNA to a $10 \mu \mathrm{l}$ of $\mathrm{H}_{2} \mathrm{O}$ and heated or 3 mins at $70^{\circ} \mathrm{C}$ ), a $0.18 \mu \mathrm{l}$ of Taq polymerase enzyme $100 \mathrm{u}$ and up to a $25 \mu \mathrm{l}$ with $\mathrm{dH}_{2} \mathrm{O}$. The PCR product were amplified by the ISSR program under the following thermal cycle conditions; $94^{\circ} \mathrm{C}$ for $5 \mathrm{~min},\left\{94^{\circ} \mathrm{c}\right.$ for $30 \mathrm{sec}, 45^{\circ} \mathrm{c}$ for $1 \mathrm{~min}$ and $30 \mathrm{sec}, 72^{\circ} \mathrm{c}$ for $2 \mathrm{~min}$, followed by 35 cycles $\}$ and $72^{\circ} \mathrm{c}$ for $10 \mathrm{~min}$. Then, a $15 \mu \mathrm{l}$ of PCR product was loaded in a $1.2 \%$ agarose gel.

\section{c) Data analysis}

Since ISSR primers are dominant markers, amplified bands were scored as 1 for presence and 0 for absence (The binary analysis) of bands by Totallab120 (nonlinear dynamics, USA) program. The UPGMA-based dendrogram and the principle coordinate analysis ( $\mathrm{PCoA}$ ) analysis were performed by using FAMD software (Schlüter and Harris, 2006).

Table 2. Names and sequences of the 10 used ISSR primers

\begin{tabular}{|c|c|c|}
\hline Polynucleotide & ID & Sequence \\
\hline 8603067895 & ISSR -3 & 5'-ACACACACACACACACYT-3' \\
8603067896 & ISSR -4 & 5'-ACACACACACACACACYG-3' \\
8603067898 & ISSR -6 & 5'-CGCGATAGATAGATAGATA-3' \\
8603067899 & ISSR -7 & 5'-GACGATAGATAGATAGATA-3' \\
8603067900 & ISSR -8 & 5'-AGACAGACAGACAGACGC-3' \\
8603067901 & ISSR -9 & 5'-GATAGATAGATAGATAGC-3' \\
8603067902 & ISSR -10 & 5'-GACAGACAGACAGACAAT-3' \\
8603067903 & ISSR - 11 & 5'-ACACACACACACACACYA-3' \\
8603067904 & ISSR - 12 & 5'-ACACACACACACACACYC-3' \\
8603067905 & ISSR - 13 & 5'-AGAGAGAGAGAGAGAGYT-3' \\
\hline
\end{tabular}

\section{RESULTS AND DISCUSSION}

\section{Molecular identification using ISSR polymor- phism}

To access molecular identification level in the 20 studied genotypes, ten ISSR primers were used to study DNA polymorphism among the sorghum genotypes as shown in Fig. (1). Table (3) showed the total number of bands, genotype positive unique marker, polymorphism percentage, band size and highest frequency band of each in the studied sorghum genotypes. All of the 10 ISSR primers that used in this study generated polymor- phic and scorable amplification fragments among the sorghum genotypes and only one fragment was found to be monomorphic with ISSR (primer 13) at fragment size of 313 bp with a $93 \%$ of polymorphism. Tadesse and Tileye (2013) using the same ISSR primers (3, 4 and 10) had amplified $100 \%$ polymorphic bands. Also similar results was found by Taher et al (2015) who showed that 3 ISSR primers out of 21 ISSR primers amplified a monomorphic band. Primer 1 and primer 25 showed a $80 \%$ of polymorphism and primer 15 gave a $66.6 \%$ of polymorphism. 

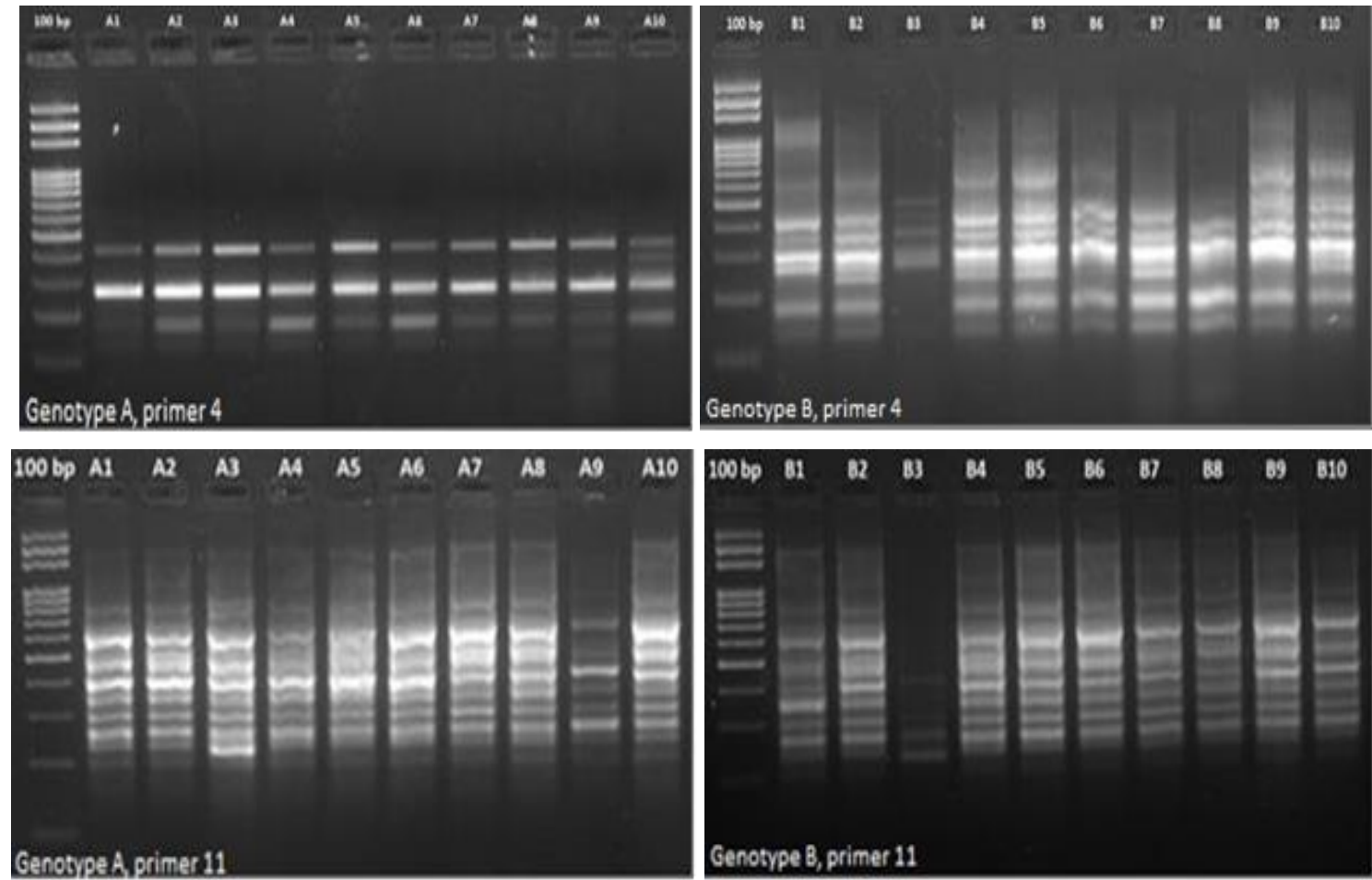

Fig. 1. An example for results of amplification based on the use of ISSR primer 4 and 11 in the 10 studied sorghum $A$ genotypes from $A 1$ to $A 10$ and $B$ genotypes from $B 1$ to $B 10$ respectively based on table (1). M: $100 \mathrm{bp}$ DNA ladder.(Primer 4 is a specific primer for B genotypes at size $390 \mathrm{bp}$ ).

A total of 152 bands were detected for the 10 ISSR primers among the 20 sorghum genotypes (Table. 3). The number of bands per primer was ranged from 8 (primer 10) to 21 (primer 8 ), with an average of 15.2 alleles across the 10 loci, and a $99.3 \%$ of polymorphism percentage. The overall size of the amplified products was ranged from 38 bp (primer 8) to $2897 \mathrm{bp}$ (primer 8). The difference in base pair size between the smallest and the largest band for a given ISSR locus was varied from 562 bp with primer 10 to 2859 bp with primer 8. Primer 10 gave eight bands with a $100 \%$ of polymorphism, Tadesse and Tileye (2013) had a similar result with the same primer (ISSR 10) which ranged from 300-600 bp, amplified seven bands with a $100 \%$ of polymorphism. This is in agreement also with Taher et al (2015) who used 21 ISSR primers to fingerprint 10 genotypes of sorghum which four of them were Egyptian. The results showed that total bands were 96 bands, most of them were polymorphic, and the percentage of polymorphism was $96.51 \%$ and number of bands per primer was ranged from 2 bands for ISSR 1 primer and 6 bands for ISSR 3 primers, with an average of 7.2 bands/ primer.

Among the 10 studied ISSR primers, eight primers were found to be useful in fingerprinting the 20 genotypes of the present study. It was found that fingerprinting of B4 genotype could be discriminated by three different markers (ISSR 8 at size of $1421 \mathrm{bp}$ and ISSR 12 at size of $2384 \mathrm{bp}$ and absence with the same primer at size of $410 \mathrm{bp}$ ), followed by six genotypes could be discriminated with two markers: A4 (ISSR 8 at size of $2897 \mathrm{bp}$ and ISSR 13 at size of $97 \mathrm{bp}$ ), A8 (ISSR 7 at size of $110 \mathrm{bp}$ and ISSR 11 at size of $1595 \mathrm{bp}$ ), A9 (ISSR 8 at size of 1705 bp and absence with ISSR 11 at size of $415 \mathrm{bp}$ ), A10 (ISSR 6 at size of 104 bp and ISSR 8 at size of 2500 bp), B1 (ISSR 4 at size of $1242 \mathrm{bp}$ and ISSR 6 at size of $173 \mathrm{bp}$ ) and B10 (ISSR 9 at size of 2784 bp and ISSR 11 at size of $1064 \mathrm{bp}$ ). Finally other five genotypes could be discriminated using at least one marker: $A 1$ (ISSR 8 at size of $49 \mathrm{bp),} \mathrm{A3} \mathrm{(ISSR} 8$ at size of 38 bp), A6 (ISSR 9 at size of 377 bp), B2 (ISSR 12 at size of $1118 \mathrm{bp}$ ) and B3 (absence with ISSR 11 at 

using ISSR markers

size of $311 \mathrm{bp})$. Primer 3 and 4 are the same primers which used by Tadesse and Tileye (2013) that were detected ISSR patterns from 200-900 bp with Ethiopian sorghum genotypes for both primers, in contrast with the Egyptian genotypes both markers were detected ISSR patterns ranged from 180 to $771 \mathrm{bp}$ for primer 3 and 153 to $1242 \mathrm{bp}$ for primer 4 . The highest frequency band in primer 3 was at size of $264 \mathrm{bp}$ and in primer 4 was at size of $194 \mathrm{bp}$.

Moreover, primers 4, 6 and 13 showed positive markers for all B genotypes which disappeared from all A genotypes at band sizes of 390, 582 and $434 \mathrm{bp}$, respectively. On the other hand, all $A$ genotypes were distinguished from all B genotypes using primer 13 at band size of $200 \mathrm{bp}$.

IT can say metaphorically that primer 4 featured for B genotypes, As there are two unique markers were amplified in, one in genotype B1 at size 1242 bp and the other one from genotype B1 to $\mathrm{B} 10$ at size $390 \mathrm{bp}$, Also primer 8 can be considered as featured for $A$ genotypes, which there are 5 unique markers at different sizes for different genotypes of $A$, in genotypes (A4, A10, A9, A1 and A3) at bands size (2897 bp, $2500 \mathrm{bp}, 1705 \mathrm{bp}, 49$ bp $38 \mathrm{bp})$. On the other hand, ISSR primer 10 is unified for both $A$ and $B$ genotypes, in genotypes $B$ the unique marker was found at size $434 \mathrm{bp}$ and in A genotypes the unique marker was appeared at $200 \mathrm{bp}$. According to the results in table (3), it was found that ISSR primers $(3,7,8,9,11$ and 12) amplified many fragments which make them polymorphic and the ISSR 13 primer Monomorphic.

Generally, molecular characterization revealed a polymorphism percentage of $99.3 \%$ for the tested ISSR markers, indicating a high level of polymorphism among the studied sorghum genotypes. Bashandy (2016) come to a similar conclusion as he used 7 ISSR primers to fingerprint 4 Egyptian sorghums landraces and he reached that the percentage of polymorphism was $84.24 \%$.

\section{Genetic distance based on ISSR analysis}

The UPGMA-based dendrogram, which was obtained from the binary data deduced from the DNA profiles using the 10 used ISSR primers of the analyzed samples, added a new dimension of the genetic similarity perspective. Two distinct clusters were created from the analysis of the pooled ISSR marker data as shown in Fig. (2). The first cluster included all A genotypes, while the second cluster contained only all B genotypes. However, the first cluster was divided into two sub-cluster, the first one included A1, A2, A3, A4, A5 and A6 genotypes, while the second one contained $A 7$, A8, A9 and A10 genotypes. Moreover, the second cluster was divided into two sub-clusters; the first one obtained all B genotypes except B1 and B3 genotypes which belonged to the second sub-cluster. Finally, the cluster analysis showed a high genetic variation among the studied sorghum genotypes and the diversity of these genotypes was in an agreement with the known pedigree of these genotypes. Taher et al (2015) likewise worked on grouping of some sorghum varieties by using UPGMA cluster analysis that correlated with the geographical origin, and agronomic traits. The result indicated that ISSR markers could be realistically used to evaluate the genetic diversity and differentiation among the used sorghum varieties.

The principle coordinate analysis (PCoA) results separated the 20 studied sorghum genotypes into four groups as shown in Fig. (3). The first group included only A3 and A4 genotypes, which the second group contained the rest of all A genotypes. In the other hand, the third group obtained B1, B2, B3, B4, B5 and B6 genotypes, whereas the fourth group represented B7, B8, B9 and B10 genotypes. This result was in the same line of the direction of that obtained from the UPGMA clustering analysis which distinguished $A$ genotypes from B genotypes. Alhajturki et al (2011) that had studied the genetic variation of 10 genotypes of sorghum using 9 ISSR primers and analyze the data by using UPGMA method. The UPGMA results were based on the genetic distances derived from ISSR markers which were in agreement and consistent with the PCoA results. The dendrogram divided the 10 genotypes into two maine clusters, and each cluster divided into two sub-clusters also the PCoA analysis separated the sorghum genotypes into four groups. Finally they reached that there was a high considerably genetic diversity among the suited sorghum genotypes.

In general, the genetic relationships among the studied sorghum genotypes derived from this study were in agreement with the known lineage of these genotypes. Menkir et al (1997) used molecular markers to analyze genetic diversity in cultivated races of sorghum and concluded that landraces of the same races grown in different habitats may have greater genetic dissimilarity than those of different races of the same habitat. We conclude that molecular markers are useful tools to assess the genetic diversity in sorghum bicolor which is considered as an important prerequisite for the improvement of sorghum cultivars and for the conservation of its germplasm. 
Table 3. Total no. of alleles, polymorphism percentage, band size, and the highest frequency band of the 20 different sorghum genotypes

\begin{tabular}{|c|c|c|c|c|c|c|c|c|c|}
\hline \multirow{3}{*}{ No. } & \multirow{3}{*}{ ISSR loci } & \multicolumn{3}{|c|}{ Number of bands } & \multirow{3}{*}{$\begin{array}{c}\text { Percentage } \\
\text { of } \\
\text { polymorphism }\end{array}$} & \multicolumn{2}{|c|}{ Allele size(bp) } & \multicolumn{2}{|c|}{$\begin{array}{l}\text { Highest } \\
\text { frequency band }\end{array}$} \\
\hline & & \multirow{2}{*}{ Total } & \multicolumn{2}{|c|}{$\begin{array}{l}\text { Genotype unique } \\
\text { marker (bp) }\end{array}$} & & \multirow{2}{*}{$\begin{array}{c}\text { Range } \\
\text { (bp) }\end{array}$} & \multirow{2}{*}{ Difference } & \multirow{2}{*}{$\begin{array}{l}\text { Size } \\
\text { (bp) }\end{array}$} & \multirow{2}{*}{ Frequency } \\
\hline & & & No. & Genotype & & & & & \\
\hline 1 & ISSR 3 & 11 & 0 & & 100 & $180-771$ & 591 & 264 & 0.90 \\
\hline 2 & ISSR 4 & 11 & 2 & $\begin{array}{l}+\mathrm{B} 1(1242) \\
\mathrm{B} 1-10(390) \\
\mathrm{B} 1-10(582)\end{array}$ & 100 & $153-1242$ & 1089 & 194 & 0.90 \\
\hline 3 & ISSR 6 & 14 & 3 & $\begin{array}{l}+\mathrm{B} 1(173) \\
+\mathrm{A} 10(104)\end{array}$ & 100 & $104-843$ & 739 & $256-582$ & 0.50 \\
\hline 4 & ISSR 7 & 18 & 1 & $\begin{array}{r}+ \text { A8 (110) } \\
+ \text { A4 (2897) } \\
+ \text { A10 (2500) }\end{array}$ & 100 & $110-1107$ & 997 & 521 & 0.70 \\
\hline 5 & ISSR 8 & 20 & 5 & $\begin{array}{c}+ \text { A9 (1705) } \\
+ \text { A1 (49) } \\
+ \text { A3 (38) }\end{array}$ & 100 & 38-2897 & 2859 & 447 & 0.80 \\
\hline 6 & ISSR 9 & 15 & 2 & $\begin{array}{c}+\mathrm{B} 10(2784) \\
-\mathrm{A} 6(377)\end{array}$ & 100 & $266-2784$ & 2518 & 377 & 0.95 \\
\hline 7 & ISSR 10 & 8 & 0 & $\begin{array}{l} \\
+A 8(1595) \\
+B 4(1421)\end{array}$ & 100 & $203-765$ & 562 & 314 & 0.85 \\
\hline 8 & ISSR 11 & 21 & 5 & $\begin{array}{c}+ \text { B10 (1064) } \\
\text {-A9 (415) } \\
\text {-B3 (311) } \\
+ \text { B4 (2384) }\end{array}$ & 100 & $213-2772$ & 2559 & 415 & 0.95 \\
\hline 9 & ISSR 12 & 19 & 3 & $\begin{array}{c}+ \text { B2 (1118) } \\
-B 4(410) \\
\text { B1-10 (434) }\end{array}$ & 100 & 114-2384 & 2270 & 410 & 0.95 \\
\hline 10 & ISSR 13 & 15 & 3 & $\begin{array}{l}\text { A1-10 (200) } \\
+ \text { A4 (97) } \\
\end{array}$ & 93 & $97-2513$ & 2416 & 313 & 1.00 \\
\hline & Total & 152 & 24 & & 99.3 & & & & \\
\hline & Iverage & 15.2 & 3.0 & & & & & & \\
\hline
\end{tabular}




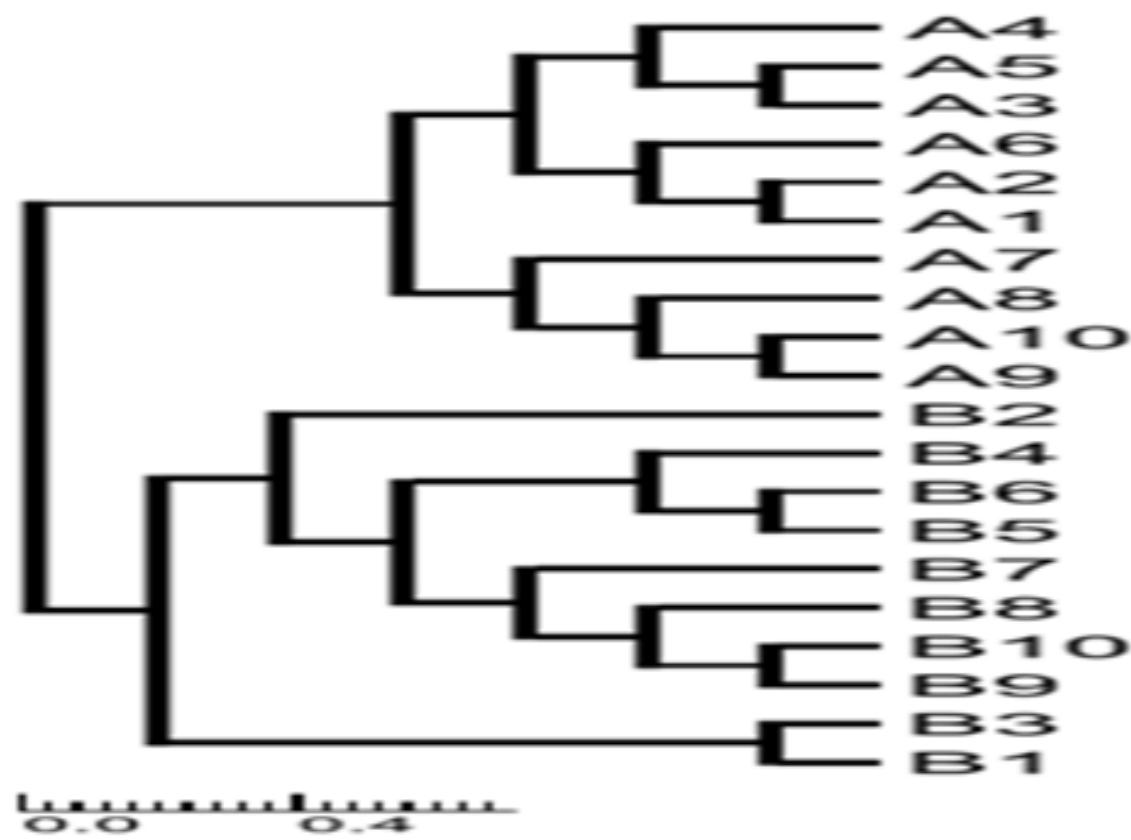

Fig. 2. Dendrogram tree showed the genetic distance among the 20 studied sorghum genotypes

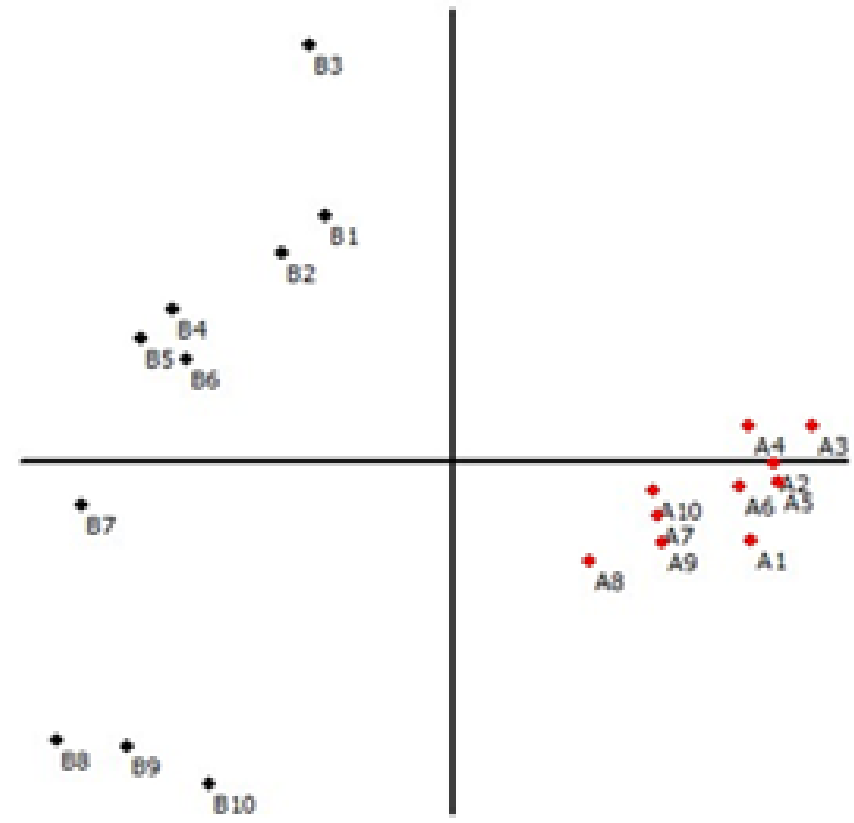

Fig. 3. PCoA analysis showed the genetic relationships among the 20 studied sorghum genotypes 
From the commercial point of view, fingerprinting is a useful tool for several applications, including its use in breeding programs, identifying relatedness of genotypes and for pedigree verification. Molecular fingerprints are useful for varietal protection to prove ownership or derivation of plant lines, as well as to prove violations and breaching of patent and plant variety protection certificates or the misappropriation of trade secrets. Such techniques will play an increasingly important role in developing, acquiring and enforcing variety proprietary rights (Atta and El-Shimi, 2003). Khalil (2013) used molecular ISSR markers to identify seven sorghum cultivars and indicating the genetic diversity among these sorghum genotypes. ISSR primers produced 34 bands and 23 which out of these bands $(68 \%)$ were polymorphic with a mean of $4.6 \mathrm{band} /$ primer. These results indicated good sources of diversity which will help breeders to evaluate genetic diversity and potentially select economically important traits such as salinity tolerance. Also Taher et al (2015) proved that ISSR technique is an efficient and functional tool in differentiating the examined varieties which were grouped according to their geographical distribution and this facilitates enhances of their use as promising parents in sorghum breeding and improvement.

\section{REFERENCES}

Alhajturki D., Al-Jamali M. and Kanbar A. 2011. Genetic Variation of Sorghum (Sorghum bicolor L. Moench) Varieties Assessed by ISSR Markers. Environmental Biology, 5(11), 35043510.

Assem S.K., Zamzam M.M., Hussein B.A. and Hussein E.H.A. 2014. Evaluation of somatic embryogenesis and plant regeneration in tissue culture of ten sorghum (Sorghum bicolor L.) genotypes. African journal of biotechnology, 13(36), 3672-3681.

Atta A.H. and El-Shimi I.Z. 2003. Genetic diversity and its relationship to some economical traits in melon (Cucumis melo L.) as revealed by isozyme and RAPD polymorphism. Egypt. J. Plant Breed., 7(1), 535-550.

Blair M.W., Panaud O. and McCouch S.R. 1999. Inter-simple sequence repeat (ISSR) amplification for analysis of microsatellite motif frequency and fingerprinting in rice (Oryza sativa L). Theor. Appl. Genet. 98, 780-792.
Bashandy T. 2016. Assessment of Genetic Diversity among Egyptian Sorghum Landraces for Grain Yield Variability Using ISSR Markers Analysis. J. Agric. Chem. and Biotechn., Mansoura Univ., Mansoura, Egypt 7(10), 263-267.

Da Silva Neto. Jose. M., de S.C.Oliveria L., Da Silva F.L.H., Tabosa J.N., Pacheco J.G.A. and Da Silva M.J.V. 2019. Use of sweet sorghum Bagasse (Sorghum bicolor ( L.) Monech) for cellulose Acetate Synthesis. Bio Resources 14(2), 3534-3553.

Doyle J.J, Doyle J.J. and Hortorism L.H.B. 1990. Isolation of plant DNA from fresh tissue. Cornell Univ., New York, USA, 53, 13-15.

El-amin H.K.A. and Hamza N.B. 2016. Comparative analysis of genetic structure and diversity of sorghum (Sorghum bicolor L.) local farmer's varieties from sudan. J. of Advances in Biology and Biotechnology, 5(3), 1-10.

Joshi S.P., Gupta Y.S., Aggarwal R.K., Ranjekar P.K. and Brar D.S. 2000. Genetic diversity and phylogenetic relationship as revealed by intersimple sequence repeat (ISSR) polymorphism in the genus Oryza. Theor. Appl. Genet. 100, 1311-1320.

Khalil R.M.A. 2013. Molecular and Biochemical Markers Associated with Salt Tolerance in Some Sorghum Genotypes. World Applied Sci. J. 22(4), 459-469.

Menkir A., Goldsbrough P. and Ejeta G. 1997. RAPD based assessment of genetic diversity in cultivated races of sorghum. Crop. Sci., 37, 564-569.

Mindaye T.T., Emma S. Mace, lan D. Godwin and David R.J. 2015. Genetic differentiation analysis for the identification of complementary parental pools for sorghum hybrid breeding in Ethiopia. Theor. Appl. Genet, 128(9), 17651775.

Nagaoka T. and Ogihara Y. 1997. Applicability of inter-simple sequence repeat polymorphisms in wheat for use as DNA markers in comparison to RFLP and RAPD markers. Theor. Apppl. Genet. 94, 597-602.

Rashed M.A., Al-Shabi J.H., Atta A.H., Sallam M.A.A., Fahmy Kh. and Abdel-Aziz S.H. 2004. Assessment of genetic diversity for some Egyptian and Yemenian Sorghum cultivars (Sorghum bicolor L.) using different molecular gentic analyses. Proceed. Int. Eng. April, 8(11), 263-277. 

using ISSR markers

Schlüter P.M. and Harris S.A. 2006. Analysis of multilocus fingerprinting data sets containing missing data. Molecular Ecology Notes 6, 569-572.

Smith J.S.C., Kresovich S., Hopkins M.S., Mitchell S.E., Dean R.E., Woodman W.L., Lee M. and Porter K. 2000. Genetic Diversity among Elite Sorghum Inbred Lines Assessed with Simple Sequence Repeats. Crop Sci., 40(1), 226-232.

Soares A.N., Vitória M.F., Nascimento A.L.S. and Ledo A.S. 2016. Genetic diversity in natural populations of mangaba in Sergipe, the largest producer State in Brazil. Genet. Mol. Res. 15(3), 1-12.

Souza S.F.B., Souza G.B., Rosado C.C.G., Miranda F.D., Soares T.C.B. and Gontijo A.B.P.L. 2015. Genetic diversity in three natural populations of Pitcairnia flammea (L.) John
(Bromeliaceae) estimated by ISSR markers. Genet. Mol. Res. 14, 1589-1590.

Tadesse H. and Tileye F. 2013. Analysis of Genetic Diversity of Sorghum bicolor ssp.bicolor (L.) Moench using ISSR Markers. Asian J. of Plant Sci. Ethiopia. 12(2), 61-70.

Taher D., Mahmmod S. and Salam L. 2015. Genetic diversity analysis of Sorghum (Sorghum bicolor L. Moench) accessions using ISSR markers. Int. J. of ChemTech Research, 8(11), 350-357.

Vijayan K. 2005. Inter Simple Sequence Repeat (ISSR) Polymorphism and Its Application in Mulberry Genome Analysis. Int. J. Indust. Entomol. 10(2), 79-86.

Zietkiewicz E., Rafalski A. and Labuda D. 1994. Genome fingerprinting by simple sequence repeat (SSR)-anchored polymerase chain reaction amplification. Genomics 20, 176-183. 


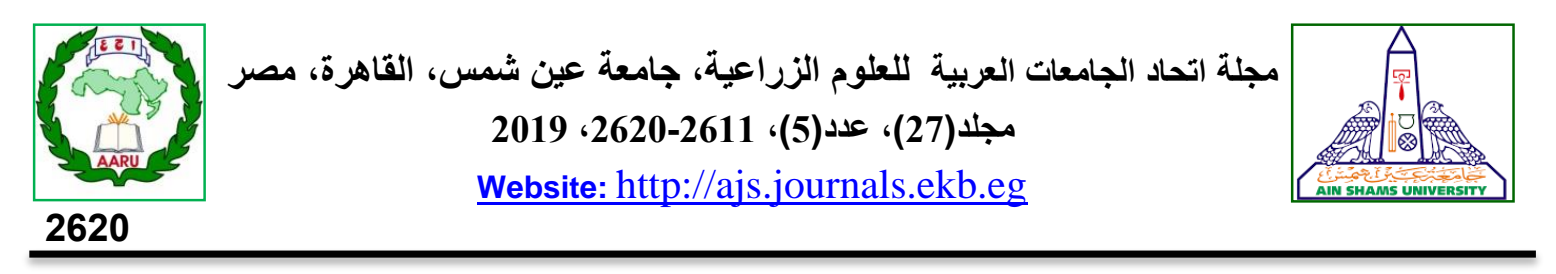

التوصيف الجزيئي لبعض التراكيب الوراثية المصرية لنبات السورجم

بإستخدام واسمات ISSR

[208]

نورهان أيمن حنفى1" - محمد عبد السلام راثد2 - شيرين كمال عاصم1 - مجدي أحمد مدكور 3

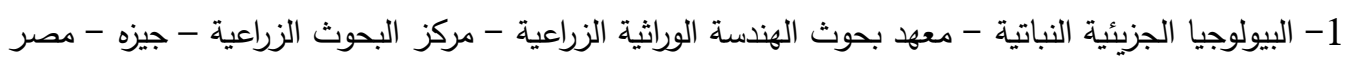

2- قسم الوراثة - كلية الزراعة - جامعة عين شمس - ص.ب.

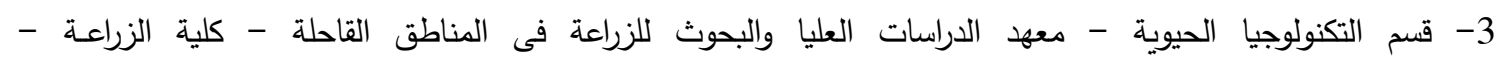

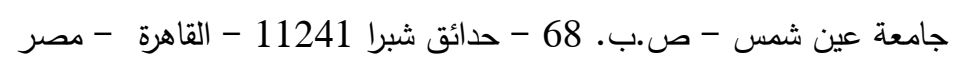

*Corresponding author: nourhan.aiman@hotmail.com

Received 28 July, 2019 Accepted 12 January, 2020

رئيسيتين بإستخدام تلك البادئات. وقد أظهر ذلك التكات

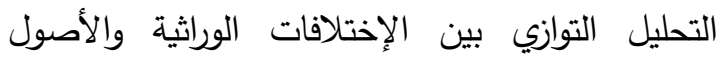

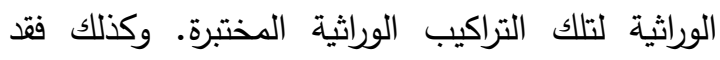

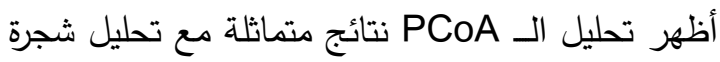
القرابة السابق. ويمكن للمربى الإستفادة من تلك تلك النتائج

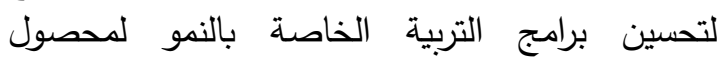

$$
\text { السورجم. - (التحبن }
$$

الكلمات الدالة: حمض DNA، واسمات ISSR، الأسمات التعدد الأشكال، الذره الرفيعة (السورجم)، تحليل الإحداثيات

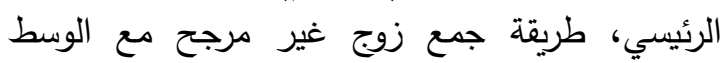

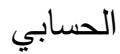

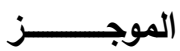

تم التثييم الوراثي لعشرين تركيب وراثي من السورجم

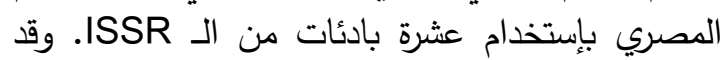

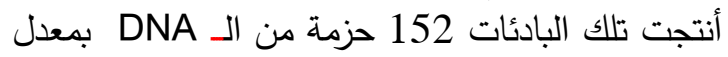

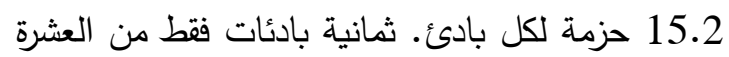

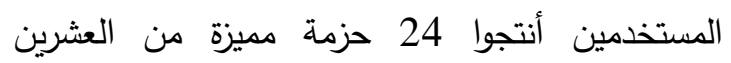
تركيب وراثي المختبرين. وقد أظهر التثييم الوراثي نسبة

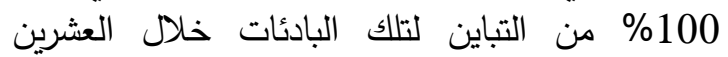

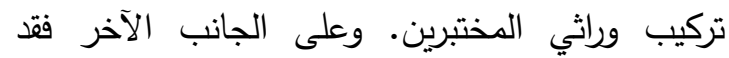

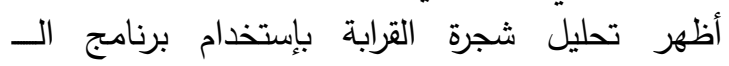
تقسيم العشرين تركيب وراثي إلى مجموعتين UPGMA 